\title{
Introduction Prospect of artificial Insemination Technology in Supporting Beef Cattle Development
}

\author{
Femi H. Elly ${ }^{1}$, Zulkifli Poli ${ }^{1}$, Charles L. Kaunang ${ }^{1}$, Agustinus Lomboan ${ }^{1}$, \\ Artise H. S Salendu ${ }^{1}$ and Rizky Ningalo ${ }^{2}$
}

Faculty of Animal Husbandry University of Sam Ratulangi, Manado,North Sulawesi, Indonesia PEMDA Regency of North Bolaang Mongondow, Indonesia

Received: 12 Nov 2020; Received in revised form: 18 Dec 2020; Accepted: 27 Dec 2020; Available online: 30 Dec 2020 (C)2020 The Author(s). Published by Infogain Publication. This is an open access article under the CC BY license (https://creativecommons.org/licenses/by/4.0/).

\begin{abstract}
The beef cattle business currently has the prospect to be developed due to the increasing demand for livestock products.The increase in population, economic level and fulfillment of people's nutritional needs had an impact on the tendency of increasing demand and consumption of beef as a source of animal protein. On the other hand, the increase in demand for meat was not matched by availability from beef cattle producers. The problem was that the development of beef cattle in the research area was slow, so the introduction of technology is needed which has an impact on increasing the population of beef cattle.The purpose of this study was to examine the prospects for the introduction of artificial insemination technology. The research method used was a survey method.The sample location was Sangkub District which was determined by purposive sampling, namely as a beef cattle development area. Respondents were beef cattle farmers who have participated in the Artificial Insemination program, as many as 33 people. The data analysis used was descriptive analysis.The prospect of introducing Artificial Insemination at the research location depends on the number of beef cattle, the number of instructors and inseminators, and the response of farmers to the program.The results showed that the beef cattle population in North Bolaang Mongondow Regency from 2018 to 2019 had increased by 7.68 percent.The largest population of beef cattle was in Sangkub District, namely 18.97 percent.The number of instructors in North Bolaang Mongondow Regency were 54 people and inseminators were 6 people. Based on the research results, it can be concluded that Artificial Insemination has the prospect of being introduced even though the success rate was considered sufficient. Suggestions need to increase the socialization of the Artificial Insemination program by the government.
\end{abstract}

Keywords - introduction, artificial insemination, beef cattle.

\section{INTRODUCTION}

The beef cattle business currently has a very big prospect because the demand for livestock products continues to increase from year to year.The increase in population, increase in economic level and fulfillment of people's nutritional needs have an impact on the tendency of increasing demand and consumption of beef as a source of animal protein.On the other hand, the increase in demand for meat was not matched by availability from beef cattle producers. As stated by Yendraliza (2018),
Indonesia had not been able to supply all the needs of beef. In connection with the fulfillment of animal protein, the government program was still mainly focused on increasing the productivity and population of beef cattle (Romjali, 2018).

The problem was that the development of beef cattle in the research area was slow, so the introduction of technology was needed that can encourage an increase in the population of cattle. Artificial insemination technology (AI) is a reproductive technology that can be applied in 
developing beef cattle. The AI technology is in accordance with the current farmers' objective conditions. Based on the researchers, the success of AI technology must be supported by improvements in livestock management as a whole and carried out simultaneously. The implementation of the application of AI technology cannot stand alone. The implementation of the application of AI technology is carried out in an integrated manner with several activities directly related to the success of the AI program. Integrated activities are intended to minimize the constraints faced in the process of implementing AI. These activities include: efforts to increase farmers' knowledge and skills in the field of reproduction, increase in inseminator skills, quality of liquid and frozen semen, and pregnancy examinations. The minimization of constraints has an impact on achieving population increase and improving genetic quality.

AI technology was important because it plays a very important role in increasing livestock development which further supports the development of livestock in the research area, even in Indonesia in general. In this case, livestock development had the aim of increasing the income and welfare of farmers, food security, environmental preservation, and regional and even state foreign exchange. Based on these thoughts, a study was conducted with the aim of examining the extent of the prospects for the introduction of artificial insemination technology.

\section{RESEARCH METHODS}

The research method used was a survey method in North Bolaang Mongondow Regency. The data sources of this research were primary and secondary data. The sample location was Sangkub District which was determined by purposive sampling, namely the district of beef cattle development. Respondents were cattle farmers who have obtained calves through the Artificial Insemination program, as many as 33 people. The data analysis used was descriptive analysis.

\section{RESULTS AND DISCUSSION}

The North Bolaang Mongondow Regency government was very concerned about the development of beef cattle in the area. This was because beef cattle were a source of income for farmers. One of the goals of the local government, in this case the Department of Agriculture and Animal Husbandry, was to increase farmers' income. Various central government programs are applied in the regions, including the SIWAB (Sapi Induk Wajib Bunting) program. The SIWAB program includes the realization of the introduction of artificial insemination (AI) technology. The introduction of AI technology was also applied in other regions in Indonesia. But based on some researchers that the development of IB has not been significant for increasing population. In fact, AI was one of the reproductive technologies that was capable of and had succeeded in improving the genetic quality of beef cattle. The use of AI technology allows farmers to produce calves of better quality in large quantities and in a short time. According to Widjaja et al (2017), AI as a form of biotechnology in the field of reproduction allows farmers to do AI without a male. The AI program was carried out by inserting semen into the genital tract and using a device called an artificial insemination gun (AI Gun).

Beef cattle breeding in North Bolaang Mongondow was introduced to beef cattle farmers, and many farmers have even joined the AI program. The prospect of introducing $\mathrm{AI}$ in the research location depends on the number of beef cattle, the number of extension agents and inseminators, and the response of farmers to the program. The population of cattle in North Bolaang Mogondow Regency according to BPS for North Bolaang Mongondow Regency (2019) can be seen in Table 1.

Table 1. Cattle Population Development in North Bolaang Mongondow Regency

\begin{tabular}{llll}
\hline No. & \multicolumn{1}{c}{ District } & \multicolumn{2}{c}{ Year } \\
\cline { 3 - 4 } & & 2017 & 2018 \\
\hline 1. & Sangkub & 2471 & 3570 \\
2. & Bintauna & 3446 & 2595 \\
3. & Bolangitang Timur & 2616 & 2740 \\
4. & Bolangitang Barat & 2824 & 2948 \\
5. & Kaidipang & 3070 & 3194 \\
6. & Pinogaluman & 3051 & 3147 \\
\hline & Total & 17478 & 18821 \\
\hline
\end{tabular}
beef cattle was found in Sangkub District, namely 18.97 percent of the population in North Bolaang Mongondow Regency. The population of beef cattle in this region had increased from 2018 to 7.68 percent in 2019. This increase can still be increased through technological innovation. The intended technological innovation was through the introduction of AI technology. This program has been carried out by the government in the research area. The development of beef cattle innovation initially began with technology dissemination since 2017. Dissemination was carried out by the government, extension agents and universities through empowerment activities. According to 
Widjaja (2017), AI technology has long been introduced and applied to cattle farms in Indonesia. However, the introduction of AI technology has not yielded maximum results. This was because the success of the AI program was influenced by the detection of lust, post thawing motility, cement handling, timing of AI, inseminator skills, cement quality, cement deposition, and the livestock itself (Widjaja et al. 2017 and Tiro, 2017). The data in Table 1 shows that the cattle population in Sangkub District had increased from 2017 by 44.48 percent in 2018. This was because Sangkub District was one of the areas for developing beef cattle. The condition of the cattle population in Sangkub District shows that this area had prospects for the introduction of AI technology.

The number of extension agents in North Bolaang Mongondow Regency was 54 people. Extension workers in the research area who deliver the introduction of AI technology have prospects for application in this area. This was because extension agents act as a bridge between technological innovation and farmers. Technological innovation can reach farmers through extension workers who carry out extension activities in the research area.

The number of inseminators in the study area was 6 people. The government, in this case the Department of Animal Husbandry, North Bolaang Mongondow District, was trying to recruit inseminators and these prospective inseminators were funded to take part in training as inseminators in order to improve their skills. This condition had an impact on the prospects for applying AI technology in the research area.

In this case, the extension agents and inseminators play a role in introducing $\mathrm{AI}$ technology innovations. Although in the field the application of AI technology innovation was influenced by various factors.Fast or not, farmers in adopting innovation were influenced by: fast or not, the process that occurs in the spread / diffusion of innovation.The diffusion of agricultural technology was an important element in supporting the progress of beef cattle farming. In theory, the adoption of AI technology was important to understand the factors associated with technology adoption.

The participation of farmers was expected to respond to the implementation of AI which was proclaimed as a government program. The participation of beef cattle farmers, among others, plays an active role in empowerment activities as the implementation of government programs. The results showed that farmers in Sangkub District responded highly to the AI technology innovation and had adopted and succeeded in utilizing the
AI technology. An example of beef cattle produced by farmer's AI is shown in Figure 1.
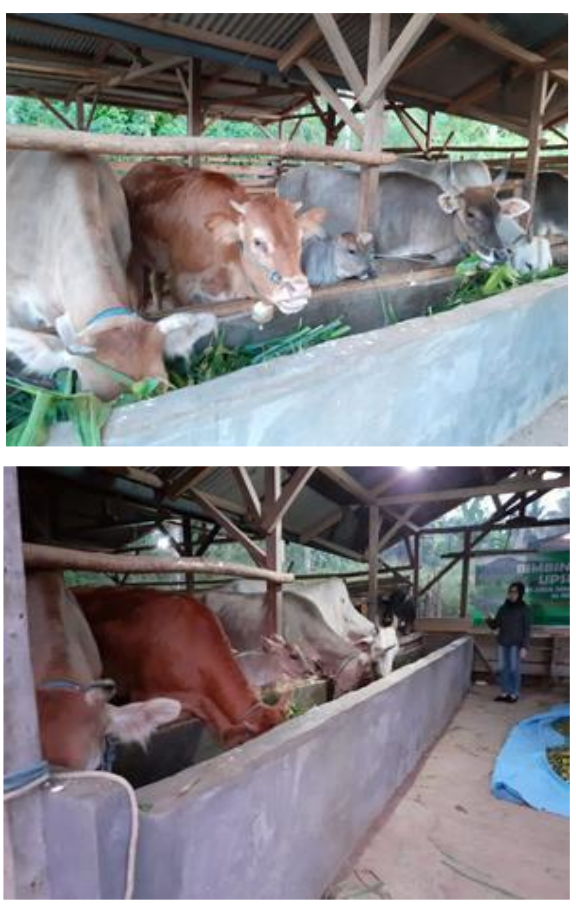

Fig.1: Artificially Inseminated calves

Figure 1 shows that farmers had responded well to the introduction of AI technology by the inseminator. The results were very satisfying to farmers. The results showed that all of the farmer's beef cattle (Figure 1) had been bred through the AI program. The farmer who owns the beef cattle had knowledge about when his cattle were in a state of heat so that in this condition the farmer directly contacts the inseminator. Farmers understand that if 21 days after AI and cattle do not experience the first lust, and also do not experience the second cycle of lust, then the cattle are declared pregnant at 42 days. The results showed that the farmers knew the objectives of AI, namely: (i) Improving the quality of cattle for the better; (ii) Reducing costs because superior bulls do not need to be brought to the farmer's place; (iii) Utilizing breed from superior bulls optimally and more widely in a longer period of time; (iv) Increase the birth rate rapidly and regularly; (v) Prevent transmission / spread of venereal disease. According to Widjaja et al (2017), in terms of benefits obtained, the advantages of AI technology were shortening the calving interval, increasing the use of superior bulls, overcoming distance and time constraints, preventing the transmission of infectious animal diseases through the genital tract, saving funds because there was no need. raising males, improving the genetic quality of cattle through superior bulls. 


\section{CONCLUSION AND SUGGESTION}

Based on the research results, it can be concluded that Artificial Insemination has the prospect of being introduced even though the success rate was considered sufficient. Suggestions need to increase the socialization of the Artificial Insemination program by the government.

\section{ACKNOWLEDGMENTS}

Thank you to the Rector, Chair and Secretary of the LPPM and the Dean of the Faculty of Animal Husbandry UNSRAT, who gave the author the opportunity to obtain research funding through SKIM RTUU.

\section{REFERENCES}

[1] Rahmah, F.F., N. I. Rahayu and Y. Yusriani, 2020. The role of artificial insemination technology (AI) and feed in supporting the acceleration of beef production and selfsufficiency in Aceh Besar District. Proceedings of the VII Animal Husbandry Technology and Agribusiness Seminar Webinar: Animal Husbandry Prospects in the New Normal Era after the COVID-19 Pandemic, Faculty of Animal Husbandry, Jenderal Soedirman University, 27 June 2020, ISBN: 978-602-52203-2-6. p: 361-371.

[2] Romjali, E. 2018. Development of Beef Cattle Innovation through "Field Laboratory" Approach. Wartazoa. 28 (2) : 069-080.

[3] Suprianto and Djuliansah. 2016. Study of Artificial Insemination Technology Application in Efforts to Increase Productivity and Income, Beef Cattle Business in Tasikmalaya Regency. Journal of the Agribusiness Mimbar, 1 (3) : 211-226.

[4] Tiro, B.M.W. 2017. Reproductive Performance of Cow Before and After Assistance at Lembu Agung Farm, Kurik District, Merauke Regency. Jurnal Ilmiah Inovasi, 17 (2) : 86-91.

[5] Widjaja, N, T. Akhdiat, and D. Purwasih. 2017. The Effect of Semen Deposition on the Success of Artificial Insemination (AI) of Ongole Crossbred Cows. Journal of Animal Science, 15 (2) : 49-51.

[6] Yendraliza, M. Rodiallah, N. Darmagiri and R. Misrianti. 2018. Analysis of Artificial Insemination Adoption Factors in West Rengat District. Journal of Indonesian Animal Husbandry, 20 (2): 108-115. 